social, and economic, systems; extraordinary psychological stresses, and a host of other difficulties, is open to question. It is clear that the ecosystem effects alone resulting from a large-scale thermonuclear war could be enough to destroy the current civilization in at least the northern hemisphere. Coupled with the direct casualties of perhaps 2 billion people, the combined intermediate and long-term effects of nuclear war suggest that eventually there might be no human survivors in the northern hemisphere. In almost any realistic case involving nuclear exchanges between the superpowers, global environmental changes sufficient to cause an extinction event equal to or more severe than that at the close of the Cretaceous, are likely. In that event, the possibility of the extinction of Homo sapiens cannot be excluded.'

\section{Shall the Living Come to Envy the Dead?}

During their investigations and presentations, the scientists were invariably scrupulous to remain objective, and to engage in no discussion of the policy implications of their findings. Nor is our Journal the place to gaze into a crystal ball of public affairs. But the reader may wish to consider whether the scientific analysis does not indicate that a pre-emptive strike by one party against another, successful to the extent that it destroyed all retaliatory capacity of any kind, would still precipitate a climatic and environmental outcome that would leave little difference between so-called victor and vanquished.

Secondly, and in so far as the 'critical threshold' beyond which a nuclear winter could be triggered occurs as low as 100 megatons (Britain's arsenal alone is much larger than this), we may consider our survival prospects when, as is likely if current trends continue (and they may well accelerate), the end of the century will see perhaps 20 nations with nuclear weapons, including those that exist in 'less than stable circumstances'-not to mention the dissident groups of sundry sorts around the world, who take increasingly extreme measures to resolve their disputes and give vent to their grievances.

NORMAN MYERS
Consultant in Environment and Development
Upper Meadow, Old Road
Headington, Oxford OX3 $8 S Z$
England, UK.

\title{
Message of the late President Andropov to IPPNW
}

Despite our usual avoidance of any conscious republication, but believing as we always do that it takes two at least to make a quarrel, we print below the following message from the late Yuri V. Andropov which was received by the International Physicians for the Prevention of Nuclear War and published on the front page of their Report (Vol. 2, No. 1, Winter 1983). The circumstances were that, in October of last year, ' $a$ delegation of IPPNW officers went to Moscow to present documents from the Third Congress of IPPNW to a representative of Yuri $V$. Andropov, President of the Presidium of the Supreme Soviet of the USSR. The delegation included.IPPNW co-presidents Drs Bernard Lown and Evgueni Chazov, and IPPNW Vice-Presidents Drs Ole Wasz-Hockert and Dagmar Sorbøe. In early November, President Andropov responded by transmitting the following message [through] the Soviet embassy in Washington, $D C$.'

$$
* * * * *
$$

'I have read with great interest and attention the appeal from your authoritative Congress to the leaders of the Soviet Union and the United States, which was recently conveyed to me. Unfortunately, having caught a cold, I could not meet with you personally in Moscow. Nevertheless, I would like to share with you some of my thoughts in connection with your appeal.

We view it as a highly humane call to avert a nuclear catastrophe. It is deeply consonant with the thinking and feelings of the Soviet leadership and of all our people.

I completely agree with your conclusion about the inevitability of truly devastating consequences of a nuclear war, should it occur. You are revealing the grave truth that people must know if they are to prevent the irremediable.

It is very important that both the work of your Congress and the documents it adopted reflect a growing realization by the medical community of the necessity to actively oppose the nuclear threat. The program you formulated of the first steps which should be taken by the nuclear powers does not in fact differ from what our country has been consistently advocating and towards which we are directing our practical efforts.

The Soviet Union rejects the idea of unleashing a nuclear war, no matter what pretext it is disguised by, as reckless, and the calls for it as criminal. We are convinced that, in the world of today, the policy of national leaders, and, in particular, of leaders of nuclear nations, should be not to accustom people to the thought of the acceptability of nuclear war, nor to strive for nuclear superiority, but, rather, to concentrate on political will to prevent a nuclear catastrophe and to insure the right of people to live.

The Soviet Union has stated its unilateral obligation not to be the first to use nuclear weapons, has made a specific proposal to freeze all nuclear weapons, has made purposeful efforts to bring about an effective agreement on the limitation and reduction of nuclear weapons, and not to permit a new round of their build-up, in Europe in particular. These positions are graphic manifestations of the Soviet Union's contribution to resolving the problem which has also motivated your movement.

We are prepared for radical solutions. It is up to the other side. Together with all people of good will, you can rest assured that the USSR will continue to do everything in its power to relax international tensions, to halt the arms race- be that on Earth or in space- and to prevent a nuclear conflagration.

I would like to wish all the participants in the movement 'International Physicians for the Prevention of Nuclear War' success in their noble and very needed endeavor.

Sincerely, Y. Andropov' 